\begin{tabular}{|c|c|c|c|c|c|c|}
\hline \multirow{4}{*}{ Impact Factor: } & ISRA (India) & $=3.117$ & SIS (USA) & $=0.912$ & ICV (Poland) & $=6.630$ \\
\hline & ISI (Dubai, UAE & $=0.829$ & РИНЦ (Russia & $=0.156$ & PIF (India) & $=1.940$ \\
\hline & GIF (Australia) & $=0.564$ & ESJI (KZ) & $=8.716$ & IBI (India) & $=4.260$ \\
\hline & JIF & $=1.500$ & SJIF (Morocco & $=5.667$ & OAJI (USA) & $=0.350$ \\
\hline
\end{tabular}

\section{SOI: 1.1/TAS DOI: 10.15863/TAS International Scientific Journal Theoretical \& Applied Science}

p-ISSN: 2308-4944 (print) e-ISSN: 2409-0085 (online)

Year: 2019 Issue: $03 \quad$ Volume: 71

Published: $29.03 .2019 \quad \underline{\text { http://T-Science.org }}$
QR - Issue

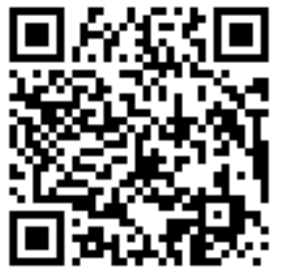

Guliston Omonturdievna Masharipova

Senior lecturer of the National Institute of

Fine Arts and Design named after Kamoliddin Behzod,

Tashkent, Uzbekistan.

\title{
SOME THEORETICAL METHODOLOGICAL FOUNDATIONS OF THE DEVELOPMENT OF IDEOLOGICAL IMMUNITY IN YOUNG PEOPLE
}

Abstract: This article covers the issues of developing ideological immunity in young people. The main emphasis on this article to be given to the methodological aspects of the subject. In particular, young people viewed as a force for society and have been scientifically-theoretically analyzed. Young people are seen as a socio-demographic group in the society and they are focused on increasing their activity. The role of youth as a determinant of social development potential has been studied. It also explains the meaning of the concept of immunity.

Key words: Youth, ideological immunity, society, development, spiritual-moral factor, social-demographic group, potential force, youth consciousness, outlook.

Language: English

Citation: Masharipova, G. O. (2019). Some theoretical methodological foundations of the development of ideological immunity in young people. ISJ Theoretical \& Applied Science, 03 (71), 425-429.

Soi: http://s-o-i.org/1.1/TAS-03-71-33 Doi: crossef https://dx.doi.org/10.15863/TAS.2019.03.71.33

\section{Introduction}

Independence is a necessary factor in the spiritual and moral renewal of members of our society, including young people, which is a force that creates conditions for socio-economic, cultural and spiritual development, ensuring the future development of society. In connection with the development of democratic thinking in society, the observed ethical and socio-cultural changes develop a positive outlook in the minds of young people. In connection with independence in the context of the development of national thinking among young people increased optimistic attitude towards positive changes in society, which is especially important in modern conditions of the formation of civil society institutions.

Due to the influence of socio-cultural, political, economic, spiritual and moral factors, the national thinking of young people acquires new importance. These parties develop a strong immunity in the minds of young people against any threats occurring in society, which is important in the context of the fact that in the process of global development there is a need to penetrate various threats. Therefore, it is necessary to study the theoretical and methodological basis for the development of youth and ideological immunity on the basis of the reality of today, to put forward proposals and recommendations that enhance the moral development of young people.
Democratic thinking in the context of civil society has created new opportunities for members of society and, in particular, young people, inadequately assigned to them a special responsibility. New thinking, positive attitude to national values, their place in the system of universal values made it possible to bring them deeply. Self-awareness and objective attitude to the past, critical and imitative perception of the events of the recent past have become an integral part of the socio-cultural and spiritual activities of young people.

From the socio-historical development it is known that as a force that affects society, young people develop regardless of the quality and condition of the existing system. In this youth development is dominated by the characteristic traits, which are due to humanistic miraculous order. Thus, the sanctity and spirituality of the independence of our people is determined by the fact that, based on the interests of national development, more attention is paid to the possibilities of self-realization of young people. In addition, in order to introduce to the universal development, along with relying on the experiences of World, the compilation of national science, the study of the achievements of other peoples has become an integral part of our daily lives.

It is gratifying that at a time when civil society institutions are being established today, stereotypes are being formed and developed that reflect the 


\begin{tabular}{|c|c|c|c|c|c|c|}
\hline \multirow{4}{*}{ Impact Factor: } & ISRA (India) & $=3.117$ & SIS (USA) & $=0.912$ & ICV (Poland) & $=6.630$ \\
\hline & ISI (Dubai, UAE & $=0.829$ & РИНЦ (Russia) & $=0.156$ & PIF (India) & $=1.940$ \\
\hline & GIF (Australia) & $=0.564$ & ESJI (KZ) & $=8.716$ & IBI (India) & $=4.260$ \\
\hline & JIF & $=1.500$ & SJIF (Morocco) & $=5.667$ & OAJI (USA) & $=0.350$ \\
\hline
\end{tabular}

positive and educational aspects of the morality of young people, secular and religious values. Thus, today relevant proposals and recommendations that represent the interests of young people, increasing their level of social activity, developing a history of responsibility for the future of the Motherland and the people.

\section{Materials and Methods}

As a social-demographic layer in the social system of society an important role is played by the young people, a quarter of our population are young people aged sixteen to thirty years. "In countries such as Uzbekistan, where young people have a high weight, it is important for a comprehensive study of this culture. According to statistics, a quarter of the population is young" [1; P. 129]. These parties are factors that indicate the relevance of the study of the problem and require attention in the social system of society in relation to the place and role of young people. So, we understand what young people mean it is permissible to look for the answer to the question.

Since then, as a result of the social development of science began to develop and to serve the interests of humanity, it is necessary to investigate the factors affecting development. Not only was a study conducted in the lives of young people, many species views were put forward. The basic encyclopedic concepts of Spirituality say that: "youth is a concept characterized by a socio-demographic group in society, features that live in a certain period of human life, defining maturity, access to the adult world and adapting to it"[2; P. 152]. This means that young people are a social process that covers a certain period of human life, in which a person's maturity as a person is ensured. Another theoretical literature emphasizes that: "youth is a socio-demographic group that is going through a period of social maturity, socialization (i.e. full penetration into the socioeconomic and spiritual structure of society)" [3; P. 6]. During this period, a person experiences the processes of socialization. As an equal member of society, during this period the social activity of young people, the formation of skills and potential of labor, the development of spiritual and moral qualities.

Focusing on the concept of youth by age was a diverse researcher. In this study, we found that scientists Z. Kodirova, V. Lisovsky and E. Sapelkina. they put forward the idea that as an object of research in science it is advisable to take young people between the ages of sixteen and thirty years [4; P. 4]. That is, from the age of sixteen, young people develop social, spiritual and moral principles of responsibility for the fate and future of the Motherland and the people rises to a qualitative level. In this, along with physical factors, less leading moral and spiritual factors. That is, starting from the age of sixteen, obtaining a youth passport of the Republic of Uzbekistan along with their personal identity is an integral part of the history of socio-political responsibility of young people.

Another definition, which is given to young people, says: "young people - a socio-demographic group characterized by age characteristics, the uniqueness of the social community" [5; P. 10]. This is how the specificity of the social characteristics of young people is characterized:

1.Opportunities for young people to gain knowledge are relatively wide;

2.They have a deeper opportunity to choose a profession;

3.During this period, young people are divided into several groups, such as, for example, a pupil, a student, a teacher, a staff member of the scope family, single, etc. on the formation of the society.

4.Based on the age and potential characteristics of young people, spiritual and moral aspects are developed and strengthened during this period

In other literature, young people are described as follows: "young people are a large social structure, having a specific character from both socio-economic and political features, as well as the emerging spiritual face, age and socio-psychological tensions. Usually young people (statistics, sociology) include 16-30 year old's" [7; P. 111]. the report said. This definition can be attributed mainly inadequate. There is no doubt that among these young people (16-30) formed socioeconomic and political characteristics in society. Indeed, the position of young people in society during this period, the economic feature is less formed attitude and participation in political processes. But we can say that during this period the spirituality of young people will be at the stage of formation, a little exaggerated. Spirituality of young people is formed from the family, after which the garden begins, starting with primary school. In the snowmobile this process consists of up to fifteen years, and then developed, say, closer to the grouse. Because when the spirituality of young people goes into the past, education is the basis of spirituality. According to Eastern customs, since the birth of the child, parents attention is paid to childs education. Education means that a person's spirituality is formed from the moment of birth. Well, let them be formulated within fifteen years, then go to the stage of development. When it comes to the essence of spirituality, it is necessary to pay attention to these aspects of the case.

Another definition states: "Youth as a permanent social group is an indicator of changes in society and determines the potential of development of society" [8; P. 138]. The above definitions certainly cover some aspects of the problem under study. In our opinion, young people are dynamically developing from physical and moral blasphemy, and as a potential force for the development of society, formed and developed socio-political, spiritual, cultural and economic color and outlook. 


\begin{tabular}{|c|c|c|c|c|c|c|}
\hline \multirow{4}{*}{ Impact Factor: } & ISRA (India) & $=3.117$ & SIS (USA) & $=0.912$ & ICV (Poland) & $=6.630$ \\
\hline & ISI (Dubai, UAE & $=0.829$ & РИНЦ (Russia & $=0.156$ & PIF (India) & $=1.940$ \\
\hline & GIF (Australia) & $=0.564$ & ESJI (KZ) & $=8.716$ & IBI (India) & $=4.260$ \\
\hline & JIF & $=1.500$ & SJIF (Morocco & $=5.667$ & OAJI (USA) & $=0.350$ \\
\hline
\end{tabular}

The sociological science studies the potential of young people in the social system of low-income society and its social consequences, such as socioeconomic and age differences, position in society. "Sociological science studies young people as a huge social group that has a social and spiritual specific phenomena in society. It is reflected not only in their differences in age, but also in the socio-economic and socio-political situation in society"[9; P. 99]. The socio-political and economic situation of young people in society should be under constant scrutiny by members of society. Because the improvement from physical and spiritual calmness is a feature inherent only to young people, and it is important to pay attention to these aspects of education.

The development of ideological immunity among young people is a priority in today's global development, thanks to which the need for ideological threats and prejudices will be eliminated with the priority of this function. It is known that the idea is a spiritual force that guides the activities of members of society as the basis of certain goals. Ideology as a term representing socio-spiritual and political goals, consisting of a rock complex, is of great importance in the development of mankind. Thus, the idea represents the goals of the members of society. This goal is manifested in the national style idea, if it is recognized at the national level. "The national idea is an idea that awakens national consciousness, embodies the identity of the nation, gives the "image" of identity, mentality, forms a sense of national responsibility, pride, faith and responsibility" [10; P. 24]. Consequently, the national idea is a strategic direction that determines the development of society as an expression of dreams and goals embodied in the inner spiritual world of the nation. That is, "...the idea that embodies the understanding of the past, present and prospects of the nation, expresses its fundamental interests and goals as an ethno-cultural unity, serves the development, is called the national rock" $[11 ; \mathrm{P}$. 15]. Let us pay attention to another theoretical source: "the idea is a powerful, deep thought that arises in human thinking, has a social character, has a strong influence on the leadership, motivates society and people to progress, leads to a single whole" [12; P. 179]. the stone of protection in the public consciousness, as a set of deep thoughts with a guiding character, and is manifested in daily activities, taking place in the thinking of members of society.

Defining the strategic direction of society, representing a set of deep ideas that contribute to national development, it is worth paying attention to the content of ideological immunity. To understand the essence of this concept, initially it is necessary to pay attention to the concept of immunity. Immunity (Immunity in German, immunity in Latin (immunity)get rid of anything. 1) the opposition of the body to any disease, that is, intolerance to the disease; 2) the existence of certain state functions without the intervention of representatives of the Central origin of the landowner ( feudal Lord); 3) state immunity - the inability of the state and its bodies in international law to file a claim with the court of another foreign state (ISC); 4) parliamentary immunity - the inviolability of the person of a member of the legislature, that is, his absence in court without the consent of this body and the right to detention. The concept of immunity in different scientific literature is interpreted on the basis of the General content. Legal terminology in the encyclopedic dictionary is explained by the fact that: "immunity - (English immunity, lat. Immunitasliberation from anything) - the term, widely used in the chest, means, that universally recognized legal norms not apply to certain subjects. In international science there are such concepts as state immunity, immunity of diplomacy, in particular. Constitutional law refers to the inviolability of individual state officials, in particular the immunity of Parliament (deputies), presidential immunity and the immunity of judges. In financial science there is a concept of tax image" [13; P. 230], - it is said in the message. This means that although the concept of immunity originally arose as a biomedical term, it has since become widespread as a concept actively used in international practice. Despite the fact that the national encyclopedia of Uzbekistan did not pay attention to the concept of immunity, but diplomatic and consular immunities describe the following: "diplomatic immunity is a set of rights and privileges granted to foreign diplomatic representatives, special missions, representatives of States in international intergovernmental organizations, their opponents and employees"[14; P. 162]. Consequently, the concept of immune system originally emerged as a medical and biological term, but later became widely used as a concept in international law. The National Encyclopedia of Uzbekistan describes diplomacy and consular immunities, even though the concept of immune system is not mentioned. There: "Consular immunity is the privileges and benefits that are provided to the consular office, the employees of this institution and their families" [15; P. 13], the statement said. Consequently, the immune system as a political term came later in the scientific and mass appeal.

The encyclopedic philosophical dictionary gives a broader and more complete definition of this concept, reveals its miracle as a socio-philosophical term. Including called: quot; the immune system (lot. Immunity-getting rid of something, getting rid of - is a set of reactions that can maintain constant internal stability of the body, to protect themselves from the effects of various properties, the penetration of external infections" [15; P. 15]. Such a definition is relatively specific to the Sciences in approaching the problem we are studying. In our opinion, in order for a term deaf to have a political essence, it is necessary to recognize the philosophical concept, to interpret the 


\begin{tabular}{|c|c|c|c|c|c|c|}
\hline \multirow{4}{*}{ Impact Factor: } & ISRA (India) & $=3.117$ & SIS (USA) & $=0.912$ & ICV (Poland) & $=6.630$ \\
\hline & ISI (Dubai, UAE & $=0.829$ & РИНЦ (Russia & $=0.156$ & PIF (India) & $=1.940$ \\
\hline & GIF (Australia) & $=0.564$ & ESJI (KZ) & $=8.716$ & IBI (India) & $=4.260$ \\
\hline & JIF & $=1.500$ & SJIF (Morocco & $=5.667$ & OAJI (USA) & $=0.350$ \\
\hline
\end{tabular}

philosophical essence of the concept. In the philosophical encyclopedic dictionary reveals relatively specific. Including: "a person forms the immune system on the basis of their knowledge and skills acquired throughout their lives as a reflecting response to external influences" [7; P. 160], the statement said. Actually, less people:

As a result of the influence of socio-spiritual factors formed attitude to the codes in the vocal and everyday way that absorb ethical factors;

These moral qualities, absorbed into human consciousness and thinking, define a person as an immune system. For deeper attention to the problem of morality, we again turn to the source: "based on the ideas of its immunity, the main parts of the philosophical immune system associated with human consciousness and thinking, its cognitive level, are as follows:

1. Knowledge that fully reflects reality, contributing to the enrichment of human spirituality and the development of society;

2. A value system formed on the basis of such knowledge and serving as a colonial shield against ideological aggression;

3. Specific goals and objectives in the socioeconomic, political, cultural and educational spheres" [7; P. 160].

\section{Conclusion}

Guidelines and goals are initially reflected in the consciousness as an integral feature of the spiritual and moral appearance of the person. The realization of the goals is the most important aspect of social activity of young people, which is a less necessary factor in achieving a stable position in relation to the species. In our opinion, as a system of immune values:

1. Develops a positive attitude to our customs and traditions;

2. Increase wit and attitude to material, cultural and spiritual heritage;

3. The above is emphasized in the fact that young people have few opportunities for the development of the Motherland and responsibility for the future of the people, as in the system of values these qualities are now indispensable factors.

With regard to ideological immunity within the concepts of immunity and the demand for this research topic, the scientific and theoretical literature describes the following: "ideological immunity (from lat. immunity - exemption from something) - the system which serves the protection of individuals, social groups, nation and society from harmful ideological influences" [16; P. 191]. So if personal immunity is a stable spiritual and moral state, a manifestation in the psyche of a particular person, when it comes to ideological or ideological immunity, it acquires a systemic essence as a set of spiritual and moral values inherent in the inner world of members of society, including young people. "The ideological immune system contributes to the education of spiritually developed, energetic of will, faith in the whole person, education of youth, able to withstand any ideological aggression of the reactionary, destructive character"[7; P. 160]. Thus, ideological immunity and upbringing are interdependent concepts. That is, if through education a person is perfect as a person, immunity is formed in it, develops as a result of the influence of spiritual and moral factors, then immunity plays an important role in ensuring the spiritual and moral well-being of a person.

The question of the development of ideological immunity among young people is mainly peculiar to the representatives of the group, who are in a dynamic socio-economic, political and spiritual growth in the social system of society, and is to ensure the stability of a strong moral position in the mind and heart to such threats in the presence of a real threat to global development in some cases.

In general, the theoretical and methodological proposal of youth issues and ideological immunity in the social system of society ensures the development of national science in conditions of independence, on the other hand, is no less important as a study showing the spiritual and moral perfection of young people, conceptual motives for increasing social activity of young people in a law -democratic state.

\section{References:}

1. Burieva, Z., \& Ibrahimov, A. A. (1998). Demographic situation of the youth and family. Public opinion, No. 2, 123-131.

2. (2009). Spirituality: a dictionary of basic concepts. The Academy under the President of the Republic of Uzbekistan. Tashkent: Gafur Gulom.
3. Qodirova, Z. R., Sharipov, A. J., Alimasov, V. A., Karimova, E. G., \& Madaeva, S. O. (2006). Socio-philosophical issues of increasing social activity and tolerance of young people. Tashkent: Publishing Institute of philosophy and law. 


\begin{tabular}{|c|c|c|c|c|c|c|}
\hline \multirow{4}{*}{ Impact Factor: } & ISRA (India) & $=3.117$ & SIS (USA) & $=0.912$ & ICV (Poland) & $=6.630$ \\
\hline & ISI (Dubai, UAE & $=0.829$ & РИНЦ (Russia & $=0.156$ & PIF (India) & $=1.940$ \\
\hline & GIF (Australia) & $=0.564$ & ESJI (KZ) & $=8.716$ & IBI (India) & $=4.260$ \\
\hline & JIF & $=1.500$ & SJIF (Morocco & $=5.667$ & OAJI (USA) & $=0.350$ \\
\hline
\end{tabular}

4. Kodirova, Z. R. (1999). The problems of increase of social activity of youth of Uzbekistan in the conditions of reforming society. Tashkent: Publishing house "National encyclopedia of Uzbekistan".

5. Lisowski, V. T. (1996). Sociology of youth. St. Petersburg.

6. Sapelkin, E. P. (2002). The social status of youth. Minsk: Technoprint.

7. (2004). Encyclopedic dictionary of philosophy. Tashkent: Publishing house of National society of philosophers of Uzbekistan.

8. Latipova, N. (2004). Young people in the social structure of Uzbekistan society. The Public opinion - Human rights, No. 3, 132-140.

9. (2000). Sociology: text of lectures. Tashkent.

10. (2005). National development philosophy. Tashkent: Academy.
11. Achildiev, A. A. (2004). National idea and interethnic relations. Tashkent: Uzbekistan.

12. (2002). Basic concepts, principles and terms of National Ideology (short explanatory dictionary). Tashkent.

13. (2000). Dictionary of foreign words and expressions. Moscow.

14. (2003). Justice terminology dictionary. Tashkent.

15. (2003). National Encyclopedia of Uzbekistan. Volume 5. Tashkent: National Encyclopedia of Uzbekistan.

16. (2007). National idea: The technology of propaganda and Glossary of terminology. Tashkent: Academy. 